Maciej Dombrowski

Uniwersytet Wrocławski, Wrocław

ORCID: 0000-0003-3255-7076

e-mail: maciej.dombrow@gmail.com

\title{
Witkacowska ironia w kontekście filozoficznym. Wokół Jedynego wyjścia S. I. Witkiewicza
}

DOI: http://dx.doi.org/10.12775/RF.2019.007

Poczekaj kotku - może odgtupniesz troche, może Tobie to kiedyś troche pomoże, że teraz sie przezwyciężysz trochę, kochanie głupawe nie zniechęcaj się przedwcześnie - będzie jeszcze i to, co Ty lubisz, ścierwo zasrane. S. I. Witkiewicz

W artykule staram się pokazać, jak do analizy dzieł Witkacego można zastosować, rzadko przywoływaną w tym kontekście, kategorię ironii. Zajmuję się problemem stylu Witkiewicza, który nastręcza licznych problemów interpretacyjnych. Staram się pokazać, że przekaz, jaki płynie z dzieł Witkacego, nie powinien być odczytywany jako jednoznacznie groteskowy lub parodystyczny i że zarówno ironia, jak i parodia czy groteska dają się pogodzić z uznaniem odczytanych „na serio” wątków "pedagogicznych" w jego utworach. Jako przykład takiego zabiegu służy analiza ostatniej powieści Witkacego - Jedynego wyjścia, w której mamy do czynienia z nieco tylko zakamuflowanym wykładem własnej doktryny filozoficznej Witkiewicza. 


\section{Uwagi o stylu Witkacego}

Stylem Witkacego zajmowano się dotąd zdawkowo - dostrzegano jego jednorodność, ale bardzo różnie ją interpretowano; już Michał Głowiński zauważył, że w tej kwestii „Sprawą - jak się zdaje najistotniejszą jest [...] tendencja zmierzająca do utworzenia stylu jednopłaszczyznowego w swym bogactwie, stylu, w którego obrębie zanikają różnice pomiędzy tym, co niskie i wysokie, subtelne i brutalne, intelektualizowane i emocjonalne, uroczyste i familiarne"1. Takie pojmowanie formy wypowiedzi Witkiewicza prowadzi do uznania, że wszystko jest w niej dozwolone, o ile służy jakiejś autorskiej intencji, mówiąc językiem Witkiewiczowskiej teorii sztuki, implikuje odpowiednie "napięcie kierunkowe". Bardzo ważny jest więc element celowościowy wypowiedzi, stale obecny w języku Witkacego - jest on tak, a nie inaczej zbudowany właśnie dlatego, że ma wyrażać określone treści. Jak zauważa autorka jednej z najbardziej wnikliwych prac analitycznych o języku autora Szewców: „Jednym z motorów działalności językowej Witkacego jest dążenie do - różnymi sposobami osiąganej - indywidualizacji języka, czyli uczynienia języka zdolnym do wyrażenia uczuć metafizycznych i przeżyć Istnienia Poszczególnego" ${ }^{2}$. Jak widać, nie są to więc ambicje małe, wręcz przeciwnie - jeśli można mówić o jakiejś filozofii języka Witkacego, to w kwestii celów należy określić ten program jako maksymalistyczny. Język nie służy więc tylko komunikacji, ale przede wszystkim dociekaniu „Tajemnicy"; autor pragnie wyrazić $\mathrm{w}$ nim to, co z istoty swej jest uznawane za niewyrażalne ${ }^{3}$. Dlatego też $w$ tym celu niszczy język zastany, burzy porządek dyskursu i z otrzymanej magmy próbuje, rekombinując zanegowany uzus językowy, stworzyć nową jakość, idiolekt ${ }^{4}$, który będzie w stanie wypowiedzieć wszystko. Trzeba więc od razu wykluczyć bez-

1 Michał Głowiński, „Witkacy jako pantagruelista”, w: Studia o Stanisławie Ignacym Witkiewiczu, red. Michał Głowiński, Jerzy Sławiński (Wrocław: Zakład Narodowy im. Ossolińskich. Wydawnictwo Polskiej Akademii Nauk, 1972), 69.

2 Magdalena Nowotny-Szybistowa, Osobliwości leksykalne w języku Stanisława Ignacego Witkiewicza (Wrocław: Zakład Narodowy im. Ossolińskich. Wydawnictwo Polskiej Akademii Nauk, 1973), 19.

3 Z tym postulatem wiąże się gwałtowny sprzeciw Witkiewicza wobec siódmego paragrafu Traktatu logiczno-filozoficzneo Wittgensteina - „O czym nie można mówić, o tym trzeba milczeć": Ludwig Wittgenstein, Tractatus logico-philosophicus, przeł. Bogusław Wolniewicz (Warszawa: Wydawnictwo Naukowe PWN, 2000), 83. Witkiewicz uważa natomiast, że "O czym nie można milczeć, o tym trzeba mówić". Obca jest mu więc analityczna powściągliwość austriackiego filozofa: Stanisław Ignacy Witkiewicz, Jedyne wyjście, oprac. Anna Micińska (Warszawa: Państwowy Instytut Wydawniczy, 1993), 13, 24. Dalej cytuję jako (JW) z podaniem stron.

4 Sformułowania „idiolekt Witkiewiczowski” używa Głowiński: Głowiński, „Witkacy jako pantagruelista”, 67. 
sensowność tego języka; dadaizm jako orientacja estetyczna był z gruntu obcy Witkacemu i taka ewentualność nie wchodzi tu w grę. Skąd zatem ta pozorna chaotyczność jego wypowiedzi, „nieumiejętność” prowadzenia narracji, ciągłe dygresje odnoszące się do samego faktu powstawania utworu, dokumentowanie procesu twórczego, często tylko jego niemożności? ${ }^{5}$

Jak sądzę, język Witkacego jest właśnie taki ze względu na cel, jaki mu przyświeca, a wskazane niedoskonałości są efektem ubocznym walki Witkiewicza z opornym tworzywem językowym. Nie jest to wyraz bezsilności czy rezygnacji z „powagi” i sensowności przekazu, ale efekt nieustannej batalii o tenże sens. Środki językowe Witkiewicza są, wbrew powierzchownemu oglądowi, celowe, rządzą się logikąa , którą należy określić jako penetrowanie wszystkich obszarów języka w poszukiwaniu swoistego kamienia filozoficznego - takich zwrotów, fraz, całych konstrukcji, które będą w stanie wyrazić byt, jego tajemnicę i ludzkie tej tajemnicy odczuwanie. Przemysław Czapliński podaje nawet nazwę takiej praktyki - jest to „logografia”7. Podobnie Głowiński widzi w językowej praktyce Witkiewicza realizację programu, który streszcza, nawiązując do słynnego hasła awangardy krakowskiej: „,[...] najwięcej słów, albo inaczej - im więcej, tym lepiej [... $]^{\prime \prime}$. Zdaniem Witkacego potoczny czy naukowy język nie jest już w stanie adekwatnie opisywać świata aby tak było, musi nastąpić zasadnicza zmiana - język powinien ulec

5 Por. na temat „,autodygresji językowych" - Nowotny-Szybistowa, Osobliwości leksykalne, 20-21.

6 Bardzo trafnie zauważa Jakowska, że język Witkacego ma - mimo swej pozornej „,beztroski” - „Tę cechę, że będąc zabawą, pozostaje [...] za w s ze w służbie logiki i zawsze w służbie sensu [podkreślenie moje-M. D.]": Krystyna Jakowska, Powrót autora: renesans narracji auktorialnej w polskiej powieści międzywojennej (Wrocław: Zakład Narodowy im. Ossolińskich. Wydawnictwo Polskiej Akademii Nauk, 1983), 53. Głowiński również idzie tym tropem i analizując terminy „metafizyczny” i "metafizyka”, pokazuje, iż wbrew pozornej dowolności, z jaką Witkacy szafuje nimi, mają one tak naprawdę całkiem ścisłe, ustalone znaczenie - nie są więc tylko „ozdobnikami”. Można w tym miejscu przytoczyć definicję z powieści: ,[...] uczucie metafizyczne, czyli [...] spotęgowane poczucie jedności osobowości, przeciwstawionej temu, co nią nie jest" (JW, s. 206). "Jedność osobowości" to centralne u Witkiewicza pojęcie filozoficzne, służące do opisu monady „od środka", eksplikacja psychologistycznej komponenty jego systemu. Za pozornym chaosem znaczeniowym kryją się więc tropy, dzięki którym można dotrzeć do sensu.

7 ,,$[. .$.$] jest to taka działalność, która złożonej i przenikającej się wzajem struk-$ turze rzeczywistości próbuje sprostać pisaniem składającym wszystko, co można powiedzieć, pisząc; innymi słowy mówiąc, metoda polega na równoczesnym aktualizowaniu wszystkich dostępnych formuł zapisu języka". Utwory, które powstają w wyniku takiego zabiegu, nazywa stosownie "logografemami": Przemysław Czapliński, „Powieści Stanisława Ignacego Witkiewicza wobec teorii czystej formy”, $P a$ miętnik Literacki, z. 2 (1988): 90.

8 Głowiński, „Witkacy jako pantagruelista”, 65. 
radykalnym przekształceniom, ale i sam autor powinien dołożyć wszelkich starań, by adekwatnie wyrazić swoje przekonania i narzucić swoją wizję odbiorcy. Funkcja impresywna i ekspresywna mowy są jednakowo ważne. Z tego też powodu tworzy Witkiewicz język, który można określić mianem "prywatnego" czy też "domowego" nasycenie pierwiastkiem indywidualnym twórcy.

Otóż takie, a nie inne ustrukturowanie języka autora Pożegnania jesieni nie jest jedynie zabiegiem powierzchownym, dostosowanym do jakiegoś konkretnego utworu, nie jest poza, a wręcz przeciwnie: u Witkacego daje się zauważyć niespotykaną jedność stylu we wszelkich przejawach działalności autora - od bogatej epistolografii, poprzez twórczość literacka, aż po prace filozoficzne. Nawet $\mathrm{w}$ tej ostatniej dziedzinie, którą Witkiewicz traktował niezwykle serio, pozostaje on wielokrotnie Witkacym, który nie jest w stanie odejść od swego prywatnego stylu ku dyskursowi w pełni naukowemu.

Gdzie zatem leży przyczyna wspomnianych problemów? Jak sądzę, można postawić tezę, że wielokrotnie Witkacy „nie przełącza” $\mathrm{w}$ odpowiednim momencie stylu z prywatnego na wymagany ogólnie przyjętą normą i mówi dalej $\mathrm{w}$ ten sam sposób, proponując treści o zupełnie odmiennej proweniencji - na przykład opisy "orgii”, zarys teorii sztuki lub diagnozę społeczno-polityczną. Taka pozorna dezynwoltura prowadzi jednak wielokrotnie do nieporozumień. Komentatorzy, choć zauważają często ową jedności stylu, to z tego faktu wysnuwają wniosek o rzekomej jednorodności nie tylko stylistycznej, ale i jedności sensów przez tę twórczość przekazywanych. Ta jedność miałaby polegać na podawaniu wszelkich sądów w jednakowym kontekście; tym wspólnym mianownikiem dla całego dorobku Witkiewicza miałyby być kpina i żart ${ }^{10}$. Wydaje się, że dzieje się tak dlatego, iż Witkacy wielokrotnie wybiera efekt zaakcentowania swojej osobowości, własnej wyjątkowości kosztem czytelności przekazu. Być może właśnie z niejasności wokół rozważań nad istotą stylu Witkiewicza biorą się tak liczne nieporozumienia prowadzące do zapoznania istoty jego twórczości i przeceniania w jego dziele elementów groteski lub parodii1 ${ }^{11}$, co objawia się

9 Jakowska, Powrót autora, 52-53. Autorka twierdzi, że wspomniana „prywatność",$[\ldots]$ płynie z »domowego " przyzwyczajenia do żartu językowego", 53. Podobny trop podsuwa, ale nie rozwija, Głowiński: Głowiński, „Witkacy jako pantagruelista", 18.

10 Temu przeciwstawia się słusznie Głowiński - stwierdza on: „,Tak kształtowana mowa, w której nakładają się na siebie różne warstwy języka, jest czymś więcej niż zgrywa, nie ma charakteru humorystycznego": Głowiński, „Witkacy jako pantagruelista", 74. To zdanie mogłoby być mottem całego mojego wywodu.

11 Obok wspominanych wyżej kpiny i żartu są to chyba najczęściej stosowane określenia w stosunku do twórczości Witkiewicza. Odniesienia do tego typu odczytań, wbrew pozorom nadal licznych, celowo pomijam. 
w rozciąganiu wpływu tych kategorii nie tylko na formę przekazu, ale i na samą treść. To z kolei prowadzi do traktowania twórczości Witkiewicza jako wyłącznie nieustannej drwiny ze wszystkiego i wszystkich, włączając w to własną osobę. Jak sądzę, jest to interpretacja przesadnie spłaszczająca wielowymiarowość dzieła autora Szewców.

Styl, który można nazwać „stylem Witkacego”, jest na tyle ekspansywny, tak silnie zrośnięty z osobą twórcy, że zawłaszcza wszystkie sfery jego wypowiedzi. Witkacy wpada więc w pułapkę własnego stylu: to, co jest być może jego największym osiągnięciem w dziedzinie słowa pisanego - niepowtarzalny, zawsze rozpoznawalny sposób mówienia staje się paradoksalnie największym niebezpieczeństwem. Skojarzenia i przyzwyczajenia odbiorcy, jakie zrodziły się już na początku obcowania z tak mocno zaakcentowanym "stylem osobnym”, nie dają się już tak łatwo zmienić. Powstaje pewien mechanizm odbioru, autor, który jest „,niepoważnym” literatem, nie może już być ",poważnym” filozofem, tym bardziej wtedy, gdy nie chce całkowicie odciąć się od swego wcale nie tak dawnego wcielenia ${ }^{12}$.

Tak dzieje się choćby w przypadku często występujących również w pismach teoretycznych zwrotów „patrz, kotku” czy "porównaj, kocie" (w Jedynym wyjściu również „patrz, kochanie”: JW, s. 8), stosowanych nagminnie w przypisach. Mogą one być przyczyną ogólnego sądu o niepoważności i parodystyczności tekstu, w którym występują. Takie twierdzenie jest jednak nieporozumieniem, gdyż wspomniane zwroty występują $\mathrm{w}$ tekstach Witkiewicza na czysto mechanicznych zasadach - semantycznie nic nie determinuje ich obecności. Stanowią one raczej rodzaj podpisu autora, potwierdzenie jego obecności w tekście. Nawet w tekście naukowym Witkacy pozostaje soba, nigdy jego styl nie jest stylem do końca bezosobowym - stąd obecność tego typu „prywatnych" wyrażeń łamiących (ale tylko pozornie) wysoki ton wypowiedzi. Podobnie jest $\mathrm{w}$ przypadku wielu neologizmów, które choć dziś mogą śmieszyć, miały - według samego Witkacego - oprócz wspomnianej wyżej funkcji stylotwórczej, mieć określone znaczenie i z czasem wejść do powszechnego użytku. Przykładem niech będzie "główniak" - kalka z niemieckiego hauptwerk (dosłownie - „główne dzieło"). Jeśli autor tak wypowiada się o swoim dziele, to nie czyni tego z nonszalanckim dystansem w celu wytworzenia humorystycznego efektu, ale żeby nie używać obcego słownictwa i zaproponować własne, które dopiero przez

12 Por. Czapliński, „Powieści Stanisława Ignacego Witkiewicza”, 94. Można postawić tezę, że twórczość Witkacego opiera się na celowym zaburzaniu relacji komunikacyjnej na linii nadawa-odbiorca lub wystawaniu jej na ciągła próbę. 
odbiorcę z początku XXI wieku może być odebrane jako niepoważne czy wręcz komiczne ${ }^{13}$.

Warto przywołać jako konkluzję ważne słowa, które w tej sprawie skierował Witkiewicz do Romana Ingardena - pisze on: „1. Trzeba zauważyć, że bądź c[o] b[ądź] jestem literatem i mam pewien sposób osobisty, bo literatura fil[ozoficzna] jest pisana jakby jednym stylem. 2. Proszę mi wybaczyć, ale for as I can see, profesorowie chcieliby zawsze, aby wszyscy robili tak, jak oni chcą $[\ldots]^{\prime \prime 14}$. Wyznanie to może stanowić klucz do zrozumienia kwestii stylu w twórczości Witkacego. Witkiewicz nie zgadza się na supremację stylu oficjalnego - taka hegemonia jest dla niego nie do przyjęcia. Nie jest on w stanie wypowiadać się w świecie zrytualizowanych, konwencjonalnych form - całość jego twórczości jest właśnie taką próbą wyjścia poza schemat i wypowiedzenia w pełni samego siebie.

\section{Ironia - parodia - groteska. Witkiewicz a postawa ironiczna}

Jak zostało już zaznaczone, wielokrotnie twórczość Witkacego, w tym Jedyne wyjście, była interpretowana poprzez kategorię parodii i groteski ${ }^{15}$. Można jednak zastanawiać się, czy często nie jest bardziej uprawomocnione posługiwanie się kategorią bardziej ogólną jaką jest ironia ${ }^{16}$.

13 Można tu jeszcze wspomnieć analizę Michała Głowińskiego, który opisując użycie przez Witkacego słowa „,bubek” na określenie Brunona Schulza, stwierdza, że nie ma ono wtedy wydźwięku pejoratywnego, jaki nadaje mu się zazwyczaj, tylko wręcz przeciwnie - jest w tym właśnie wypadku określeniem jak najbardziej pozytywnym: Głowiński, „Witkacy jako pantagruelista”, 69. Wydaje się, że u Witkacego takie użycie języka, nieliczące się z uzusem, stanowi swoistą normę; hipotezę tę można rozszerzyć na kategorie groteski i parodii - w tym względzie Witkiewicz postępował równie często wbrew zwyczajom i konwencjom.

14 Stanisław Ignacy Witkiewicz, Roman Ingarden, Korespondencja filozoficzna, 89.

15 Zob. np. Jan Błoński, Witkacy na zawsze (Kraków: Wydawnictwo Literackie, 2003), 232-244; Lech Sokół, Groteska w teatrze Stanisława Ignacego Witkiewicza (Wrocław: Zakład Narodowy im. Ossolińskich. Wydawnictwo PAN, 1973).

16 Nie chcę przez to powiedzieć, że jest tak zawsze, w wielu wypadkach groteska czy parodia mogą dominować, tak dzieje się przede wszystkim $\mathrm{w}$ dramatach Witkiewicza, powieści zawierają więcej fragmentów dyskursywnych, mniej lub bardziej jawnie odautorskich; to one powoduja, że można mówić o tym, co określam dalej jako postawę ironiczną. O ironii u Witkacego jako osobnym zjawisku wspomina Jerzy Speina: Jerzy Speina, Powieści Stanisława Ignacego Witkiewicza. Forma i struktura (Toruń: Towarzystwo Naukowe, 1965), 112. Ironii poświęcił swój szkic Tomasz Bocheński: Tomasz Bocheński, Ironia czasu, czyli historia Witkacowskiej autoironii, w: Tomasz Bocheński, Witkacy i reszta świata (Łódź: Officyna 2010), 59-73. Jak zaznacza: „Wiele tekstów Mistrza z lat trzydziestych zawiera fragmenty, które nazwałbym [...] prywatnym teatrem autoironicznym [...]" (Bocheński, Witkacy i reszta świata, 72). 
Wniosek taki płynie z zarysowanej wcześniej analizy stylu Witkacego i chęci wskazania na niejednoznaczność charakteru jego wypowiedzi, wiąże się również z próbą odejścia od schematycznego podporządkowywania tej twórczości kategoriom groteski i parodii. Pojęcie ironii, właśnie jako szersze zakresowo, zawierające więcej niuansów znaczeniowych, a mieszczące w sobie zarówno elementy groteski, jak i parodii czy satyry wydaje się $\mathrm{w}$ wielu wypadkach - z wyżej zaakcentowanych względów - bardziej adekwatne.

Definiować ironię można na wiele sposobów - zwięzłą jej definicję podał Piotr Łaguna: „Ironia jako postawa jest to taka świadomość, którą cechuje poczucie kontrastu, sprzeczności między zjawiskami świata zewnętrznego lub wewnętrznego danej jednostki oraz poczucie własnej wyższości ironizującego; przy czym uświadomiona przez jednostkę sprzeczność zostaje podporządkowana określonej idei bądź wizji świata i bytu ludzkiego"17.

Można zapytać: czy elementy wyszczególnione w powyższym zestawieniu znajdują potwierdzenie $\mathrm{w}$ postawie podmiotu mówiącego w Jedynym wyjściu i świecie przedstawionym utworu? Przede wszystkim kontrast pomiędzy światem zewnętrznym a uniwersum autorskim w przypadku tej właśnie powieści jest aż nazbyt widoczny - to właśnie autor jest tu najważniejszą postacią ${ }^{18}$, to on aranżuje i podporządkowuje sobie w całości utwór, wykorzystuje go dla swoich partykularnych celów, stoi ponad fabułą i narratorem lub przynajmniej się z nimi zrównuje. Kontrast towarzyszy więc poczuciu wyższości często graniczącemu z megalomanią. Ideami nadrzędnymi, którym zostały podporządkowane wszelkie inne składniki utworu, są: filozofia Witkiewicza, jego poglądy historiozoficzne, estetyczne oraz społeczne. Nad wszystkim panuje wszechobecna ironia. Parodia i groteska byłyby w tym kontekście ter-

17 Piotr Łaguna, Ironia jako postawa i jako wyraz (Wrocław: Wydawnictwo Literackie, 1984), 25. Autor odrzuca, podnoszoną przez innych badaczy, kwestię sprzeczności między „myślą a formą jej wyrażania”, co nie jest do końca zrozumiałe. W przypadku Jedynego wyjścia taka sprzeczność jest jedną z podstawowych kategorii: por. tamże, 92-93. Podana definicja akcentuje „postawę” ironiczna, nie należy jednak zapominać, że dany utwór „,w niej” powstały przejmuje jej cechy - sam jest konstrukcją ironiczną. Można więc mówić o zawartym w ironii silnym pierwiastku indywidualnym, jednostkowym, ale i drugim biegunie - ironii zawartej w samym dziele; oba elementy są jednakowo ważne. Te dwa zasygnalizowane piętra narracji zauważa również Speina: „Ironia u Witkiewicza - pisze on - uwypuklająca dysproporcje świata przedstawionego i służąca jego ocenie - pojawia się bowiem nie tylko w płaszczyźnie narracji, daje się również zaobserwować [...] w konstrukcji świata przedstawionego": Speina, Powieści Stanisława Ignacego Witkiewicza, 112.

18 Ostrożne utożsamienie autora $\mathrm{z}$ narratorem $\mathrm{w}$ wypadku akurat tego utworu nie prowadzi, jak sądzę, do sprzeniewierzenia się kanonicznym rozróżnieniom teoretycznoliterackim. Tutaj nie zajmuję się szerzej tym zagadnieniem. 
minami o węższym zakresie znaczeniowym ${ }^{19}$. Pierwszy z nich jawiłby się jako najbardziej określony i ograniczony - według utartych określeń znaczyłby tyle, co "typ komicznego naśladowania danego wzorca literackiego (dzieła, stylu, gatunku)"20. Można oczywiście rozszerzać znaczenie tego terminu ${ }^{21}$, ale wtedy ulega ono rozmyciu. Parodię przyjęło się uznawać za występującą w funkcji służebnej wobec groteski - tak określa to również w stosunku do dzieł Witkacego cytowany już Ryszard $\mathrm{Nycz}^{22}$. Tę ostatnią znowu powołując się na Łagunę, który rozważa jej związki z ironią, można określić jako: „Grę przeciwieństw, świat rządzący się prawami kontrastu, wobec którego podmiot literacki bezustannie zmienia swą pozycję, wydłużając bądź skracając dystans" ${ }^{\prime 23}$. Powieść Witkiewicza nie mieści się $\mathrm{w}$ ramach parodii ani groteski z tego względu, że jak określił to w odniesieniu do groteski (można jednak chyba ten sąd rozszerzyć na parodię) Wolfgang Kayser: „Twórca groteski nie może i nie powinien podejmować prób usensowienia $[\ldots]^{\prime 24}$. Witkiewicz wykracza poza ten paradygmat, gdyż - jak zaznaczałem - jego twórczość jest wciąż poszukiwaniem, choć często na sposób groteskowy, tegoż sensu. Widać więc, że ani parodia, ani groteska nie tłumaczą w sposób wystarczający konstrukcji i budowy semantycznej utworów Witkacego. Pojęciem najbardziej do tego celu predysponowanym okazuje się ironia, często pomijana w egzegezach twórczości autora Pożegnania jesieni. Oczywiście ironia nie jest terminem jednoznacznym - można kojarzyć ją z wersją, której rodowód sięga czasów antycznej Grecji, uosabianą przez Sokratesa, ale i nowożytnym rozumieniem, które nadał jej w XIX wieku

19 W nowszej literaturze przedmiotu trafić można na odmienne ujęcie, w którym to parodia jest traktowana jako kategoria nadrzędna, zob. Linda Hutcheon, Teoria parodii. Lekcja sztuki XX wieku, przeł. Agnieszka Wojtanowska, Witold Wojtowicz (Wrocław: Wydawnictwo Atut, 2007). Referowanie aktualnego stanu badań przekracza jednak znacznie zakres tego artykułu.

20 Ryszard Nycz, Tekstowy świat. Poststrukturalizm a wiedza o literaturze (Kraków: Universitas, 2000), 200-201.

${ }^{21}$ Przykładem takiej praktyki są analizy zawarte w cytowanej powyżej pracy: Nycz, Tekstowy świat, 200-229.

22 Nycz, Tekstowy świat, 213.

23 Łaguna, Ironia jako postawa, 76.

24 Wolfgang Kayser, „Próba określenia istoty groteskowości”, przeł. Ryszard Handke, w: Groteska, red. Michał Głowiński (Gdańsk: słowo/obraz terytoria, 2003), 26. Trzeba jednak zaznaczyć, że inny autor w cytowanym zbiorze wypowiedzi krytycznoliterackich mówi słusznie o „,dogłębnie krytycznym” stosunku twórcy groteski do świata - twierdzi on, że: „Ma ona powołanie "metafizyczne«, odsłania i uwypukla, ponieważ zmusza spojrzenie do wniknięcia w struktury, a na tym poziomie wszelka rzeczywistość zaczyna się mniej lub bardziej wykrzywiać": Jean Onimus, "Groteskowość a doświadczenie świadomości”, przeł. Krystyna Falicka, w: Groteska, 73. W tym wypadku groteska ma już wiele wspólnego z ironią. 
Friedrich Schlegel (ironia romantyczna). Oba podejścia mocno się różnią ${ }^{25}$.

Ironia, jak podaje znaczenie tego terminu badacz filozofii starożytnej Giovanni Reale, to źródłowo tyle, co „maskowanie, ukrywanie”26. Ironia sokratejska objawia się przede wszystkim w pozornym przyjęciu reguł gry przeciwnika w sytuacji polemicznej walki - oto mędrzec schodzi z piedestału i przyznaje przeciwnikowi rację; następnie $\mathrm{w}$ odpowiednio przemyślanych krokach sprowadza stanowisko adwersarza do sprzeczności - ad absurdum. Interlokutor nie ma innego wyjścia, jak tylko z pokorą przyjąć rozwiązanie, które poda wtedy Sokrates - jest więc pokonywany własną bronią. Ważny jest cel Sokratesa - otóż ironię stosował on po to, by „zmusić rozmówcę do zastanowienia się nad sobą" ${ }^{27}$. Równie istotny jest sposób, w jaki proces ten się odbywa, jego osnową jest bowiem żart, humor, ale - jak pisze dalej Reale: „Nigdy też $\mathrm{w}$ tej grze nie brakuje przyciszonego tonu powagi, aczkolwiek często tę szczyptę powagi odkryć można jedynie w celu, któremu żart ma służyć. Cel ten jest jednak zawsze poważny [podkreślenie moje - M. D.]"28.

Wspomniane już wyżej ujęcie Schlegla wyznacza drugi biegun rozumienia ironii zapoczątkowanej przez ironię sokratejską ${ }^{29}$ - Schlegel sam zresztą w swej koncepcji ironii odwołuje się do postaci mędrca z Aten. Jak pisze:

Ironia sokratejska jest jedynym całkowicie mimowolnym, a jednak całkowicie rozmyślnym udawaniem. [...] Nie powinna nikogo łudzić, poza tymi, którzy ją mają za złudzenie i albo cieszą się z rozkosznego szelmostwa, że cały świat został wystrychnięty na dudka, albo złoszczą się, gdy poczuja że odnosi się to także do nich. Wszystko powinno być w niej żartem i powaga, wszystko prostodusznie otwarte i wszystko głęboko zniekształcone. [...] Zawiera ona i budzi poczucie nierozwiązywalnego konfliktu między bezwarunkowym i uwarunkowanym, między niemożliwością i koniecznością pełnej komunikacji. Jest najbardziej wolna ze wszystkich licencji, albowiem dzięki niej wychodzi się poza siebie same-

25 Na temat szczegółowego porównania zob. Tomasz Ososiński, Ironia a jednostka. Koncepcja ironii Friedricha Schlegla i Sokratesa (Warszawa: Wydawnictwo Uniwersytetu Warszawskiego, 2014). Autor ujmuje te dwa modele ironii jako opozycyjne - Sokratejska jest ironią etyczna, kojarzoną z działaniem, propozycja Schlegla jest określona jako estetyczna i związana ściśle z dziełem literackim.

26 Giovanni Reale, Historia filozofii starożytnej, przeł. Edward Iwo Zieliński, t. 1 (Lublin: Wydawnictwo KUL, 1999), 375.

27 Tamże.

28 Tamże. Istotą ironii jest właśnie wymieszanie komiczności i powagi. W przypadku Sokratesa dialektyczne związanie tych dwóch elementów służy jednemu celowi - jest nim dotarcie do wiedzy pewnej, prawdy. Na ten temat zob.: Romana Patyk, „Sokrates wiszący”, Edukacja Filozoficzna, nr 37 (2004): 269-281.

29 Piotr Łaguna, Ironia jako postawa, 22. 
go, a jednak jest też ściśle poddana prawu, ponieważ jest bezwarunkowo konieczna. Jest to bardzo dobry znak, gdy harmonijni spłyciarze wcale nie wiedzą jak mają rozumieć tę ciągłą autoparodię, gdy co rusz wierzą lub niedowierzaja póki nie pomiesza im się w głowie i zaczną brać żart poważnie, a to, co poważne, mieć za żart ${ }^{30}$.

Schlegel kojarzony jest z ideą tzw. ironii romantycznej ${ }^{31}$, która dość luźno miała nawiązywać do wzorca antycznego. Powoli Sokrates-nauczyciel ulegał przekształceniu $\mathrm{w}$ artystę o swoistym, stawiającym go ponad tłumem etosie. $W$ tym kontekście pojawia się nieustanna dialektyka „,autokreacji i samozniszczenia"32, tak charakterystyczna dla współczesnego rozumienia ironii, co ujął najlepiej chyba Søren Kierkegaard, gdy pisał: „O ironii można rzec, że tylko wtedy poważnie traktuje »nic«, gdy niczego nie traktuje poważnie. Ironia zawsze ujmuje »nic« w opozycji do »coś«i chwyta się nicości, aby wyzwolić się od traktowania czegokolwiek z powagą. Ale »nic « też nie bierze na serio, w przeciwnym razie coś jednak traktowałaby poważnie" 33 .

Postawa ironiczna jest potwierdzeniem absolutnych mocy kreacyjnych autora - można powiedzieć, że w momencie zastosowania zasad ironii romantycznej autor po raz pierwszy zdobywa pełnię władzy nad samym sobą i swym dziełem, staje się demiurgiem o iście boskich prerogatywach. Schlegel w swoich uwagach o ironii podnosił również kwestię dychotomii pomiędzy wewnętrznym znaczeniem dzieła $\mathrm{i}$ jego zewnętrzną formą. Ta ostatnia niekoniecznie musi odpowiadać nastrojem i rodzajem użytych środków jego wewnętrznej treści ${ }^{34}$. Nie wnikając w szczegóły, można powiedzieć, że u Witkacego co krok widać podobną prawidłowość. Skłaniam się ku tezie, że Witkiewicz w swojej postawie wiecznego ironisty i autoironisty łączy obydwa omówione wyżej sposoby rozumienia ironii. Pozwala mu to, kiedy tego chce, mówić poważnie w sposób niepoważny (pozornie) lub uciekać w artystowską pozę wyższości wobec ogółu, gdy tylko najdzie go taka ochota. Jest to więc poza wygodna i „plastyczna”, dopuszczająca liczne warianty pośrednie. Taka łatwość zmiany ról rodzi jednak określone zagrożenia, o których już wspominałem.

30 Friedrich Schlegel, Fragmenty, przeł. Carmen Bartl, oprac. Michał Paweł Markowski (Kraków: Wydawnictwo UJ, 2009), 27-28.

31 Choć sam nie używał tego terminu. Zob. Schlegel, Fragmenty, 13 (przypis 44).

32 M. Żmigrodzka, „Etos ironii romantycznej po polsku”, w: Problemy wiedzy o kulturze: prace dedykowane Stefanowi Żótkiewskiemu, red. Alina Brodzka, Maryla Hopfinger, Janusz Lalewicz (Wrocław: Zakład Narodowy im. Ossolińskich, 1986), 525.

33 Søren Kierkegaard, O pojęciu ironii z nieustającym odniesieniem do Sokratesa, przeł. Alina Djakowska (Warszawa: K.R., 1999), 263.

34 Zob. Maria Żmigrodzka, „Ironia romantyczna”, w: Stownik literatury polskiej XIX wieku, red. Józef Bachórz, Alina Kowalczykowa (Wrocław: Ossolineum, 1994), 378-379. 
Witkiewicz był często, szczególnie przez współczesnych, odbierany jako niegroźny błazen, jego twórczość była więc wygłupem, zgrywą czymś z gruntu niepoważnym, "szwindlem i blagą"35. Rzeczywiście element groteski lub parodii jest łączony z kategorią komizmu, a mówiąc o ironii, nie można również zapomnieć o śmiechu. Wcale nie musi on jednak być kojarzony z rechotem wesołka, lekkoducha i żartownisia - wręcz przeciwnie: błazen to postać tyle śmieszna, co tragiczna, obarczona wcale nie śmieszną wiedzą o świecie ${ }^{36}$. Po pierwsze, błazen jest kimś z zewnątrz, jest sam i nie może liczyć na niczyje „wspólnictwo”, jest zawsze outsiderem, „obcym”. Po drugie, musi swoje prawdy, często gorzkie dla innych, podawać właśnie w ironicznej masce (zawsze autoironicznej) - jest dzięki temu, przynajmniej częściowo, kimś wolnym, może mówić to, za co innych spotkałaby niechybnie kara. Jest jednak równocześnie niewolnikiem swego położenia - jego maskę odbiera się często jako jego jedyną praw$\mathrm{de}^{37}$. Witkiewiczowska ironia wydaje się być wyrazem właśnie tak rozumianej błazeńskiej postawy - Witkacy rzeczywiście "blaguje”, ale za tą „blagą" coś jeszcze się kryje. Zagubienie wzajemnych zależności między parodia, groteską a nadrzędną wobec nich ironia, która odwołuje się do systemu wiedzy autora, niezrozumienie, iż „wypowiedź ironiczna ma to do siebie, że jej zamierzony przez mówiącego sens jest odmienny czy wręcz odwrotny niż dosłowne znaczenie użytych w wypowiedzi wyrazów"38, powoduje nadmierne akcentowanie roli samej groteski lub parodii i nadawanie im rangi podstawowej, której nie mają. Zapomina się wtedy, że błazeństwo Witkiewicza nie jest tylko błazeństwem, że jego postawa bliższa jest właśnie Stańczykowi, błaznom Szekspira niż trefnisiowi, którego żart jest tylko rozrywką i naigrywaniem się, niczym więcej.

Jak więc można określić wzajemne zależności ironii, parodii i groteski w Jedynym wyjściu? Parodia i groteska są bez wątpienia konstytutywnymi kategoriami budującymi tkankę powieści Witkiewicza - jej osnową jest jednak postawa ironiczna (i autoironiczna) prezentowana przez głównego bohatera utworu, którym okazuje się sam autor. Wielokrotnie parodia i groteska są zjawiskami, które należy lokalizować na poziomie stylu, a nie sensu utworu - można powiedzieć, że nie naruszają one wte-

35 Sformułowanie Karola Irzykowskiego z jego recenzji przedstawienia Kurki wodnej - cyt. za: Stanisław Ignacy Witkiewicz, "O Czystej Formie” i inne pisma o sztuce, oprac. Janusz Degler (Warszawa: Państwowy Instytut Wydawniczy, 2003), 168.

36 Małgorzata Elżanowska, „Błazeństwo - sprawa poważna”, Ogród 4 (1991): 307.

37 Szerzej na temat postaci błazna i historii tego motywu w literaturze zob.: Mirosław Słowiński, Błazen. Dzieje postaci i motywu (Poznań: Wydawnictwo Poznańskie, 1990); Monika Sznajderman, Błazen. Maski i metafory (Warszawa: Iskry, 2014).

38 Małgorzata Frankiewicz, „Dwa spojrzenia na obrzeża metafizyki”, Ogród 2 (1992): 407. 
dy wartości edukacyjnych, utylitarnych, w jakie autor (tu zgoda - dość przewrotnie) uposażył swój utwór. Powieść, choć stanowi na pozór konglomerat heterogenicznych elementów, jest jednak całością nad wyraz spójną a dzieje się tak właśnie dzięki jednolitej perspektywie autorskiej.

\section{Jedyne wyjście jako realizacja programu edukacyinego Witkiewicza}

Wcześniejsze dokonania powieściowe Witkacego wyraźnie różnią się od Jedynego wyjścia; powołując się znów na przywołanego już badacza, ich konstrukcję można streścić krótko - otóż autor „,[...] przeplata długie rozmowy i medytacje sensacyjnymi scenami" ${ }^{39}$. Ewolucję powieści Witkiewicza można dobrze zobrazować na przykładzie pojawiających się już w Pożegnaniu jesieni tak zwanych „informacji". Stanowią one dopowiedzenie tekstu głównego, rodzaj powieściowych didaskaliów. W Nienasyceniu różnica między tymi dwoma elementami jest już mniej widoczna. Jedyne wyjście stanowi zobrazowanie momentu, w którym owe „informacje” ulegają całkowicie stopieniu z tkanką powieści, często można mieć jednak wrażenie odwrotne - to tekst dyskursywny wysuwa się na pierwszy plan ${ }^{40}$. W omawianej powieści Witkiewicz zagęszcza stronę intelektualną dzieła, natomiast z sensacyjności nie pozostaje już praktycznie nic. Powieść przestaje być powieścia, a zaczyna przypominać traktat, w którym narrator (tu z dużą dozą prawdopodobieństwa utożsamiony z autorem) propaguje własny system filozoficzny - monadyzm biologiczny. Na tle poprzednich powieści zabieg ten jest widoczny bardzo wyraźnie. Wcześniej (a także w dramatach), jeśli występowały wątki filozoficzne (a działo się to często), filozofia była traktowana jako jeden z elementów dzieła, nigdy nie była aż tak wprost wykładana. Perspektywa autorska była często ukrywana, a postacie wypowiadały kwestie niebędące wyrazem poglądów autora, wręcz przeciwnie - chodziło często o ich ośmieszenie. W przypadku Jedynego wyjścia sytuacja jest odmienna, mamy do czynienia $\mathrm{z}$ agitacją na rzecz własnego systemu, czytelnik jest bombardowany terminologią i twierdzeniami przepisanymi wprost $\mathrm{z}$ rozpraw teoretycz-

39 Daniel Gerould, Stanisław Ignacy Witkiewicz jako pisarz, przeł. Ignacy Sieradzki (Warszawa: Państwowy Instytut Wydawniczy, 1981), 366.

40 Jeśli dramaty Witkacego można określić jako "laboratorium formy”, to powieści wypadałoby nazwać, zgodnie z teorią „powieści-worka” - „laboratorium idei”. Trzeba jednak pamiętać, że w przypadku Jedynego wyjścia mamy do czynienia z prezentacją już gotowej doktryny filozoficznej, ukazaniem tyko inscenizowanego aktu jej powstawania. Idee filozoficzne powstają zatem gdzie indziej, powieść służy do ich ukazania i rozreklamowania. 
nych Witkiewicza ${ }^{41}$, to język abstrakcyjnych pojęć filozoficznych staje się głównym ",bohaterem” omawianej prozy.

Dlaczego tak się dzieje? Ważny, jak sądzę, jest tu kontekst historyczny. Otóż należy pamiętać, że w latach trzydziestych Witkacy odkrywa w sobie pasję popularyzatora lub nawet „wychowawcy narodu" ${ }^{\prime 2}$. Powstaje wiele artykułów o charakterze popularyzatorskim, głównie na tematy filozoficzne, owocem tej postawy są jednak przede wszystkim dwa wyjątkowe dzieła - jedno traktujące o swoistym, polskim charakterze narodowym i próbie jego sanacji, drugie poświęcone wszelkiego rodzaju używkom i narkotykom ${ }^{43}$. Nie będę się skupiał na analizie tych prac, wypada jednak zająć stanowisko wobec sporu, który można lakonicznie wyrazić jako pytanie: Czy Witkacy pisał na serio? Otóż wydaje mi się, że mimo wszystko jednak tak i nie mamy powodu sądzić, że było inaczej. Inne pytanie dotyczy trafności formy przekazu i tu można mieć uzasadnione wątpliwości, jednak imputowanie Witkacemu jakichś niskich intencji („flota" i „,szpryngiel”, mówiąc jego językiem) uznałbym za daleko idące nadużycie. Odmienne zdanie na ten temat zaprezentował w swej analizie Narkotyków Grzegorz Grochowski ${ }^{44}$. Odrzuca on zdecydowanie koncepcję „utylitarno-dydaktycznych intencji” Witkiewicza ${ }^{45}$. Komentator odwołuje się przede wszystkim do dandyzmu jako klucza do interpretacji postawy Witkiewicza ${ }^{46}$. Uznaje, że forma językowa, pomieszanie stylistyczne, autoironia, które prezentuje Witkacy w tekście Narkotyków, wykluczają możliwość przekazywania poważnych treści. Jak zauważa: ,[...] rola wychowawcy narodu jest tylko przymiarką do kolejnego stylu mówienia, jedną z masek, zakładanych na potrzeby bezinteresownej gry, elementem bardziej złożonej, kilkupoziomowej konstrukcji" ${ }^{47}$. Grochowski po prostu nie wierzy w zapewnienia Witkiewicza, który zastrzega we wstępie do Narkotyków: „,[...] piszę poważnie i chcę wreszcie coś bezpośrednio pożytecznego zdziałać [...]" ${ }^{\prime 48}$. Uważam, że przedłuże-

41 Przede wszystkim z jednej, o czym za chwilę.

42 Janusz Degler, „Witkacy - wychowawca narodu”, Odra 10 (1976): 96.

43 Stanisław Ignacy Witkiewicz, Narkotyki. Niemyte dusze, oprac. Anna Micińska (Warszawa: Państwowy Instytut Wydawniczy, 1993).

${ }_{44}$ Grzegorz Grochowski, „Hybrydyzacja w służbie autokreacji. »Narkotyki« Stanisława Ignacego Witkiewicza", w: Grzegorz Grochowski, Tekstowe hybrydy. Literackość i jej pogranicza (Wrocław: Funna, 2000), 161-203. Polemikę z odczytaniem Grochowskiego, z którą w pełni się zgadzam, przeprowadziła Marta Skwara: Marta Skwara, Wśród Witkacoidów: w świecie tekstów, w świecie mitów (Wrocław: Wydawnictwo Uniwersytetu Wrocławskiego 2012), 119-122.

45 Skwara, Wśród Witkacoidów, 167.

46 Tamże, 165-167. Jak lapidarnie, ale znów bardzo celnie, zauważa Skwara: „Witkacy dandysa grywał, ale nim nie był" (tamże, 210).

47 Grochowski, „Hybrydyzacja w służbie autokreacji”, 167.

48 Witkiewicz, Narkotyki. Niemyte dusze, 7. Zob.: Grochowski, „Hybrydyzacja w służbie autokreacji", 173. 
niem tej postawy „społecznikowskiej” jest też Jedyne wyjście jako próba edukacji filozoficznej w formie powieściowej. Oczywiście to nie jedyny sens i cel tego utworu, ale uważam, że wpisanie go w ten szerszy obraz jest kluczowe dla interpretacji ostatniej powieści Witkacego.

\section{Jedyne wyjście a relacja autor-czytelnik. Polemika z Zofią Mitosek}

Warto przy tej okazji zastanowić się nad sytuacją układu autor-czytelnik, bo wydaje się, że jej właściwe odczytanie może stanowić klucz do zrozumienia nierozpoznanej funkcji parodii, a szczególnie autoparodii $\mathrm{w}$ Jedynym wyjściu oraz samej ironii. Tłem dla poniższych rozważań jest jedno z odczytań powieści, które zaprezentowała Zofia Mitosek ${ }^{49}$. Wybieram je, bo jest reprezentatywne dla pewnego szerszego sposobu odczytania dzieł Witkiewicza, o jakim była już mowa, a które akcentuje generalną ich niepoważność.

Komentatorka widzi w Jedynym wyjściu realizację poetyki, która jest , $[\ldots]$ oparta na zasadzie kompromitującego kontekstu [...]"50. Jak zaznacza, w powieści „[...] mamy do czynienia z realizowaną na wielu piętrach utworu parodią"51. Uważam jednak, jak już zaznaczałem, że odwołując się do ironii sokratejskiej - można odczytać parodię zawartą w tym utworze jako autorską maskę mającą na celu zmylenie czytelnika. Zarówno parodia, jak i autoparodia służą więc Witkacemu jako rodzaj konia trojańskiego, kamuflażu, który pozwala w sposób niedosłowny przemycić w tekście literackim nie do końca literackie treści. Sądzę więc, że wbrew temu, co pisze Mitosek, strategia Witkacego jest o wiele bardziej przemyślana i „przebiegła” oraz że badaczka literatury zwyczajnie go nie docenia. Odwołując się do motta artykułu, postrzegam parodię i groteskę w Jedynym wyjściu jako swoisty haracz, który musi zapłacić autor po to, by przemycić głębsze treści. Aby to zrobić, nie ma lepszego sposobu, jak tylko (pozornie) przypodobać się niskim gustom odbiorców $^{52}$. I to właśnie robi Witkacy, taktyka jest straceńcza, ale wobec upadku poziomu publiczności literackiej okazuje się ,jedynym wyjściem”.

49 Zofia Mitosek, „Jak ugryźć Witkacego (Stanisław Ignacy Witkiewicz »Jedyne wyjście«)", w: Zofia Mitosek, Poznanie (w) powieści - od Balzaka do Masłowskiej (Kraków: Universitas, 2003), 156-172.

50 Tamże, 161, 167.

51 Tamże, 165. Autorka wspomina też o grotesce (tamże, 170).

52 Można taką postawę odnieść do świata współczesnego. Żyjąc w kulturze karnawału, nie można cały czas być poważnym mędrcem. Najlepszym sposobem jest wtedy spowodowanie, aby odbiorca czuł się cały czas nie nauczanym, ale zabawianym. 
Witkacy nie pisze "do szuflady" ${ }^{53}$ - jak chce Mitosek - raczej próbuje stworzyć wrażenie, że jest to właśnie taki utwór, do którego autor nie przywiązuje większej wagi - jest to jednak tylko złudzenie. Witkiewicz ma pełną świadomość, z jakim odbiorcą jego utwór się spotka; krótko mówiąc - odbiorca już nie tylko wirtualny, ale i realny jest rzeczywiście „kretynowaty”. Witkiewicz pisze powieść właśnie dla niego - musi więc obmyślić odpowiednią strategię, sposób podania treści dyskursywnych (oczywiście przy założeniu nieobecnej u Mitosek funkcji edukacyjnej powieści filozoficznej). Autor wybiera więc jedyną możliwą drogę - fortel bardzo przypominający postawę Sokratesa - staje po stronie czytelnika, identyfikuje się z nim, trafnie przewiduje jego reakcje - jest to jednak zabieg pozorowany, mający uśpić czujność takiego odbiorcy. Ten ostatni dostaje to, czego oczekuje - jakąś choćby wątłą akcję, opisy erotyczne $^{54}$ i wreszcie to, na co czeka znienawidzona przez Witkacego „publiczka” - autoparodię, wielokrotnie powtarzane, że aż nieszczere: „Tak - jestem "gówniarzem Witkacym «"55. Okazuje się, że przekaz musi być dostosowany do poziomu odbiorcy - traktat filozoficzny może być czytany tylko przez specjalistów. W kontakcie z przeciętnym „konsumentem literatury" treści filozoficzne muszą być odpowiednio „opakowane" - temu może służyć właśnie parodia i groteska, generalnie styl „niski" jako o wiele bardziej bezpośredni i komunikatywny. Oczywiście taka strategia nie musi przynieść powodzenia - autor Jedynego wyjścia postanawia podjać jednak takie ryzyko. Odczytuję więc szereg partii Jedynego wyjścia jako realizację formuły edukacji przez zabawę, temu służy dość ostentacyjne, a w gruncie rzeczy pozorne zrównanie pozycji podmiotu mówiącego z odbiorcą tekstu, skrócenie dystansu. Filozof nie przemawia już z wysokości Akademii, tylko schodzi do „ludu”, staje się Sokratesem, który rozmawia z niepiśmiennym niewolnikiem jak równy z równym, gdyż jest jednocześnie błaznem-mędrcem. Taka postawa może jednak prowadzić do porażki autora, bo pełne przyswojenie tych „przemycanych" treści wymaga jednak sporych kompetencji odbiorcy ${ }^{56}$.

53 Mitosek, „Jak ugryźć Witkacego", 156. Wiadomo skądinąd, że Witkiewicz mocno zabiegał o druk powieści i wiązał z nią duże nadzieje. Zob. A. Micińska, „Nota” w: JW, 258-260.

54 Nie trzeba chyba dodawać, że przychodzi to Witkacemu z widocznym trudem; można odnieść wrażenie, że gdyby tylko mógł, w ogóle powieści by nie pisał zająłby się tylko własną retoryką.

55 W sąsiedztwie tego zwrotu znajdujemy jednak znamienną uwagę zawartą w przypisie - narrator stwierdza tam wprost: „Piszę tak, aby wywołać sympatyczną nić porozumienia między sobą a wychowaną jedynie na »Wiadomościach Literackich «polską pseudointeligencją" (JW, 18). Jest to bardzo dobitne wyrażenie postawy autorskiej - autoparodia nie jest więc do końca szczera, skoro służy takiemu „utylitarnemu" celowi.

56 Wspominany już w kontekście krytycznym interpretator Narkotyków antycypuje taki typ lektury, odnosząc się właśnie do kategorii ironii. Jak pisze: „Ta »głębsza«, 
Ironia musi być w pewnym momencie odczytana właśnie jako ironia, należy „wziąć ją w nawias”, inaczej jej zastosowanie jest przeciwskuteczne. Sądzę, że właśnie z takim wypadkiem niezrozumienia intencji utworu mamy do czynienia w przypadku omawianej interpretacji Jedynego wyjścia ${ }^{57}$. Postawa autoparodii u Witkacego to wynik mechanizmu zarysowanego powyżej, ale i samej sytuacji autora, który jest zmuszony przez okoliczności do takich działań, to też elementem obrony, maski, która w jakiś sposób chroni go przed atakiem, bo go wyprzedza. To jeszcze bardziej komplikuje sytuację autor-czytelnik. Mitosek widzi w Jedynym wyjściu wyłącznie parodię, gdzie nie ma miejsca na ton serio, filozofia niespecjalnie komentatorkę interesuje, postrzega ona powieść zdecydowanie jednowymiarowo.

Jak więc w świetle powyższych ustaleń prezentują się proponowane przez Mitosek próbki analiz samego tekstu? Z pewnością nie są one do końca przekonujące. Jako przykład można przytoczyć komentarz do następującego fragmentu powieści, gdzie narrator utyskuje:

Nie było żadnej intelektualnej atmosfery - paru błaznów spotworniałych $\mathrm{w}$ podlizywaniu się zidiociałym tłumom $\mathrm{w}$ imię zaropiałej już lekkości i w imię zjełczałego dawno, wskutek nadużyć, dowcipu (co to jest więcej wart niż najmędrsze, panie dziejku, nudne, ciężkie „niemieckie” traktaty) stroiło jeszcze ohydne miny na jakimś dawnym pra-podium narodowego pseudowisielczego humorku ${ }^{58}$.

Pozornie trudno nie zgodzić się z komentarzem Mitosek, która dostrzega $\mathrm{w}$ powyższym cytacie kpinę narratora ze stereotypów (mówi o „niemieckości”) - cudzysłów przy wyrażeniu „niemieckie” miałby stanowić „,[...] znak dystansu narratora wobec wypowiedzi zacytowanej

"prawdziwsza« komunikacja dokonuje się bowiem na styku konceptualnej mediacji oraz milczenia, poprzez to, co jest jedynie sugerowane, dawane do odgadnięcia. Podjęcie tej gry jest więc uwarunkowane zwiększonymi wymaganiami wobec czytelnika - oczekiwaniem odpowiedniej kulturowej kompetencji, pewnej swobody w operowaniu konwencjami oraz wzmożonej aktywności w rekonstruowaniu sensów implikowanych. [...] Ucieczka od poważnej dosłowności nie oznacza ugrzęźnięcia w błahości, ale służyć ma wytrąceniu czytelnika z rutyny, wprowadzeniu go w stan twórczego niepokoju”. Grochowski, „Hybrydyzacja w służbie autokreacji”, 175-176. Tu akurat w pełni zgadzam się z Grochowskim. Podobnie argumentuje Skwara: Skwara, Wśród Witkacoidów, 215-216.

57 O takim niebezpieczeństwie pisała Skwara. Komentatorka zauważa, że: „Tam, gdzie szło o rzeczy dla autora Ontologii Ogólnej ważne, np. o teatr, głos filozofa, teoretyka teatru czy bohatera dramatów, mógł różnić się tylko »ramą modalną", sposobem zaistnienia w konkretnym tekście artystycznym, teoretycznym bądź filozoficznym. Tam, gdzie tezy dzieł historiozoficznych czy estetycznych zostają wykpione $\mathrm{w}$ dziele artystycznym [...], mamy raczej do czynienia z szyderczym gestem obrony, a nie negacji własnych twierdzeń". Skwara, Wśród Witkacoidów, 11 (przypis 9).

$58 \mathrm{JW}, 136$. 
w nawiasie [...]”, której podmiot jest identyfikowany „familiarnym zwrotem "panie dziejku«"59. Mitosek zauważa, że takie fragmenty tworzą "obraz mentalny danego narodu" ${ }^{60}$. To wszystko prawda - stereotyp zostaje ośmieszony, ale raczej jest to stereotyp odbioru filozofii niemieckiej przez odbiorcę popularnego (nie chodzi tu tylko o generalne ośmieszenie „stereotypu obcego narodu”, jak mówi komentatorka). Nie tylko stereotyp jest ośmieszony, ale i odbiorca, dla którego traktaty, szczególnie niemieckie, są "ciężkie". Parodia, która tutaj występuje, jest zabiegiem celowym, określającym stanowisko autora w tej właśnie sprawie, podobnie jest z analizowanym dalej przez Mitosek zjawiskiem "francuskości”. Tym razem jednak kpiny narratora z lekkości, racjonalności i dowcipu cechującego kulturę francuską można przyjąć jako szczery atak już nie na sposób odbioru, ale właśnie na "francuskość" jako taką. Skąd to wiemy? Z innych wypowiedzi Witkiewicza, który wielokrotnie tak właśnie wypowiadał się o wpływach francuskich w rodzimej kulturze. Mitosek, choć sama pisze o "piętrowości” parodii, postrzega ją zdecydowanie jednostronnie i płytko. Jak pisze: „[...] nic w powieści nie upoważnia do stwierdzenia, że jej autor lekceważył Francuzów, a doceniał umysłowość Niemców $[\ldots]^{\prime \prime 61}$. Mitosek zdaje się dostrzegać w powieści jedynie niczemu niepodporządkowaną grę znaczeń, dlatego też zrównuje ona wszystkie poziomy utworu - każdy dyskurs jest jednakowo ważny - to jednak prowadzi do spłyconego odczytania. Owszem, parodia dotyka wszystkiego i wszystkich, łącznie z narratorem o wyraźnych cechach autora, ale ta jej wszechobecność powoduje, że nie wydaje się ona szczera, jest raczej rodzajem sztafażu, pozy, paradoksalnie jest jej zbyt dużo, by brać ją na poważnie. Komentatorka popełnia więc błąd, jakim jest nieliczenie się z perspektywą autora - choć mówi sama o „satyrze”, która jest przecież pisana z pewnego określonego punktu widzenia, i pyta o związek powieści z innymi utworami pisarza. Tutaj dochodzimy do sedna. Otóż problem z interpretacją Mitosek bierze swój początek w sposobie potraktowania przez nią kontekstu powieści, która bez niego jest praktycznie niezrozumiała ${ }^{62}$. Sama wikła się dzięki temu w sprzeczność. Najpierw autorytatywnie odrzuca ona ów kontekst. Jak pisze:

59 Mitosek, "Jak ugryźć Witkacego", 162.

60 Tamże.

61 Tamże, 166.

62 Podobnie wygląda to w przypadku analiz Grochowskiego, który sprzeciwiając się wizji Witkacego jako zaangażowanego społecznie "wychowawcy narodu”, zauważa w kontekście Narkotyków, że: „,[..] taka gwałtowna wolta powinna zostawić jakieś ślady w innych dziełach. Tymczasem powstałe mniej więcej w tym samym czasie utwory - Szewcy i Jedyne wyjście - wprawdzie przynoszą pewne zmiany i odbiegają od wcześniejszych dokonań, ale ani trochę nie sprawiają wrażenia edukacyjnych pogadanek napisanych przez świeżo upieczonego adepta utylitaryzmu" (Grochowski, „Hybrydyzacja w służbie autokreacji”, 163). Komentator stosuje tu taktykę sprowa- 
Wbrew temu, co sugeruje auktorialna narracja, w powieściowym układzie wzajemnie się przewartościowujących wyobrażeń kulturowych daremnie można by szukać stałego miejsca oparcia, jakim jest punkt widzenia autora. [...] Co więcej - powieść nie dostarcza żadnych dowodów na to, że przytaczane w niej rozważania Witkiewicza z traktatu Nowe formy w malarstwie czy z rozprawy O zaniku uczuć metafizycznych w zwiazku z rozwojem społecznym są przekonaniami autora Jedynego wyjścia (autora rozumianego jako twórca tekstu powieści Jedyne wyjście). [...] Skoro uniwersalną zasadą dzieła jest parodia, kwestionująca wszystkie sposoby mówienia o rzeczywistości, nie ma powodu, aby sądzić, że ten jeden uprzywilejowany w pismach teoretycznych Witkiewicza filozoficzny obraz świata nie podlegał ogólnopowieściowemu mechanizmowi degradacji ${ }^{63}$.

Nieco dalej stawia jednak pytanie: „Istotne jest [...], jaka postawa kulturowa kryje się za prezentowanym w Jedynym wyjściu warsztatem pisarskim i w jakim stosunku pozostaje ona do wyrażonych explicite w pismach Witkiewicza twierdzeń o strukturze rzeczywistości" ${ }^{64}$. Odpowiedź nie przynosi zmiany i jest zgodna z wcześniejszymi ustaleniami. Otóż: „o implikowanej przez stylistykę Jedynego wyjścia wizji świata można powiedzieć, że jest to zespół przekonań, który wyklucza jakąkolwiek formę mówienia na serio" ${ }^{65}$. Znów więc widać, że w interpretacji badaczki nie ma miejsca na kontekst, bo podlega on każdorazowo neutralizującemu, homogenizującemu dyskurs działaniu parodii.

Sądzę jednak, że od kontekstu nie tak łatwo się uwolnić i jego „zneutralizowanie" przez parodię nie może wystarczyć. Świadczy o tym również co innego. W przywołanym wyżej cytacie w kwestii kluczowego dla powieści kontekstu pism filozoficznych Witkiewicza mamy do czynienia z poważnym lapsusem. Mitosek ma rację, mówiąc o „traktacie" $^{\prime 66}$ - tyle że ów traktat, w kontekście którego możemy rozpatrywać Jedyne wyjście, nosił tytuł Pojęcia $i$ twierdzenia implikowane przez pojęcie

dzenia do absurdu i wyolbrzymiania argumentów strony przeciwnej, pomija przy tym cały zespół tekstów publicystyczno-filozoficznych Witkacego powstały w tym samym czasie.

63 Mitosek, „Jak ugryźć Witkacego”, 166-167.

64 Tamże, 167.

65 Tamże.

66 Nie wiedzieć czemu, rozbija go na dwa teksty - wspomniana zaraz „rozprawa” O zaniku uczuć metafizycznych w związku z rozwojem społecznym jest przecież integralną częścią książki Nowe formy w malarstwie i wynikajace stąd nieporozumienia i stanowi jej IV część. Por.: Stanisław Ignacy Witkiewicz, „Nowe formy w malarstwie i wynikające stąd nieporozumienia", w: Stanisław Ignacy Witkiewicz, Nowe formy w malarstwie i wynikająe stąd nieporozumienia. Szkice estetyczne, oprac. Janusz Degler, Lech Sokół (Warszawa: Państwowy Instytut Wydawniczy, 2002), 5-214. 
Istnienia ${ }^{67}$ i ukazał się w 1935 roku, choć jego ukończenie datuje się na 1932 rok, więc praca nad ostateczną redakcją tego, jak sam Witkacy go określał, „,hauptwerku” zbiegła się z pisaniem powieści ${ }^{68}$. Praca, o której mówi Mitosek, była wczesną rozprawa, głównie poświęconą estetyce, w której tak istotne dla Witkiewicza zagadnienia ontologiczne były jeszcze marginalne, a sam autor określał ją w latach trzydziestych jako "naiwną trochę z obecnego punktu widzenia" ${ }^{69}$. Taka pomyłka w sprawie podstawowej, jaką jest periodyzacja twórczości autora Szewców, stawia pod znakiem zapytania zasadność twierdzeń badaczki w omawianej kwestii $^{70}$. Jak starałem się wykazać gdzie indziej ${ }^{71}$, zbieżność między ustaleniami Izydora a Witkiewicza z Pojęć $i$ twierdzeń... jest uderzająca i nie ma odpowiednika w jego pozostałych utworach literackich.

Morał z powyższych rozważań powinien być chyba taki: nie bierzmy Witkacowskiej niepowagi zbyt poważnie, często nie jest ona tym, czym się wydaje - to znaczy wyłącznie kpina, żartem dla żartu, pustym śmiechem (nie twierdzę, że czasami nie jest). Dzieło Witkacego okazuje się na tyle pojemne, że dopuszcza różne style lektury i odsłania różnorodne sensy, również te „na serio”, i nie jest to żadną dla tej twórczości ujmą. Witkacy oczywiście nie jest - gdy nim bywa - klasycznym pedagogiem; jest nauczycielem ironicznym, bo czasy są takie, a nie inne, wymuszają pewną pozę. Jakakolwiek koturnowość kłóciła się też z osobowością autora (trudno wyobrazić sobie Witkiewicza jako szacownego

67 Stanisław Ignacy Witkiewicz, „Pojęcia i twierdzenia implikowane przez pojęcie Istnienia”, w: Stanisław Ignacy Witkiewicz, „Pojęcia i twierdzenia implikowane przez pojęcie Istnienia" i inne pisma filozoficzne (1902-1932), oprac. Bohdan Michalski (Warszawa: Państwowy Instytut Wydawniczy, 2002), 145-354.

68 Warto przypomnieć, że praca nad tym filozoficznym opus magnum trwała z przerwami od 1917 do 1932 roku, w tym czasie Witkiewicz sporządził i następnie przerabiał kolejno sześć redakcji traktatu.

${ }^{69}$ Stanisław Ignacy Witkiewicz, O idealizmie i realizmie, w: Stanisław Ignacy Witkiewicz, "Nauki ścisłe a filozofia” i inne pisma filozoficzne (1933-1939), oprac. Maciej Dombrowski i Magdalena Bizior-Dombrowska (Warszawa: Państwowy Instytut Wydawniczy, 2014), 96.

70 Stanowisko Mitosek razi tym bardziej, że - jak sama mówi - interpretacja, którą przedstawia, jest „gruntownie zmienioną" wersją (co można rozumieć jako „poprawioną") dużo wcześniejszej rozprawy, ogłoszonej w 1977 roku: por. Mitosek, Jak ugryźć Witkacego, 167. Jak wskazuje data pierwotnie opracowanej rozprawy, wtedy rzeczywiście teksty Witkiewicza mogły być dla autorki trudno dostępne (choć oczywiście nie nieosiągalne). Porównanie obu wersji, wbrew zapewnieniom Mitosek, nie wskazuje na większe zmiany.

71 Maciej Dombrowski, „Filozofia w "Jedynym wyjściu« Stanisława Ignacego Witkiewicza", w: Z filozoficznych inspiracji literatury. Materiaty z Ogólnopolskiej Sesji Naukowej Doktorantów. 21-22 października 2004, red. Marzenna Cyzman i Katarzyna Szostakowska (Toruń: Wydawnictwo Naukowe UMK, 2005), 135-147; Maciej Dombrowski, „Filozofia w przebraniu powieści. O »Jedynym wyjściu « Stanisława Ignacego Witkiewicza", Rocznik Podhalański XI (2016): 339-364. 
profesora uniwersytetu w typie Kazimierza Twardowskiego). Witkacy łączy więc w swojej postawie dziedzictwo poważnego w zamiarach Sokratesa, ale i bliższego nam, bawiącego się formą, estetycznie zorientowanego ironisty romantycznego Schlegla, do tego dołóżmy jeszcze dandyzm i wpływy młodopolskie. Mieszanka jest więc nieco „wybuchowa”, ale - jak starałem się pokazać - „w tym szaleństwie jest metoda". Pozwala to na uniknięcie częstej kliszy interpretacyjnej, która każe postrzegać każde działanie Witkacego poprzez pryzmat żartu i wiecznej drwiny dla niej samej. Jak sądzę, można też dzięki temu nieco inaczej spojrzeć na tak podstawowe kategorie literaturoznawcze jak parodia czy groteska poprzez uznanie, że nie zawsze są one wszechogarniające i że są takie fragmenty twórczości Witkacego, gdzie nie wystarczają one do adekwatnego opisu zjawisk, z którymi mamy do czynienia. Wtedy powinniśmy poszukać jakiejś innej, bardziej pojemnej kategorii. Starałem się przekonać, że najlepszą kandydatką okazuje się, rzadko stosowana $\mathrm{w}$ analizach dorobku Witkacego, ironia.

\section{Bibliografia}

Błoński Jan. 2003. Witkacy na zawsze. Kraków: Wydawnictwo Literackie.

Bocheński Tomasz. 2010. Ironia czasu, czyli historia Witkacowskiej autoironii. W: Tomasz Bocheński, Witkacy i reszta świata. 59-73. Łódź: Officyna.

Czapliński Przemysław. 1988. „Powieści Stanisława Ignacego Witkiewicza wobec teorii czystej formy". Pamiętnik Literacki 2: 75-105.

Degler Janusz. 1976. „Witkacy - wychowawca narodu”. Odra 10: 95-97.

Dombrowski Maciej. 2005. „Filozofia w »Jedynym wyjściu« Stanisława Ignacego Witkiewicza". W: Z filozoficznych inspiracji literatury. Materiaty z Ogólnopolskiej Sesji Naukowej Doktorantów. 21-22 października 2004. Toruń. Red. Marzenna Cyzman i Katarzyna Szostakowska. 135-147. Toruń: Wydawnictwo Naukowe UMK.

Dombrowski Maciej. 2016. „Filozofia w przebraniu powieści. O »Jedynym wyjściu « Stanisława Ignacego Witkiewicza". Rocznik Podhalański XI: 339-364.

Elżanowska Małgorzata. 1991. „Błazeństwo - sprawa poważna”. Ogród 4: 305-309.

Gerould Daniel. 1981. Stanistaw Ignacy Witkiewicz jako pisarz, przeł. Ignacy Sieradzki. Warszawa: Państwowy Instytut Wydawniczy.

Głowiński Michał. 1972. „Witkacy jako pantagruelista”. W: Studia o Stanisławie Ignacym Witkiewiczu, red. Michał Głowiński, Jerzy Sławiński. 59-82. Wrocław: Zakład Narodowy im. Ossolińskich.

Grochowski Grzegorz. 2000. „Hybrydyzacja w służbie autokreacji. »Narkotyki« Stanisława Ignacego Witkiewicza". W: Grzegorz Grochowski, Tekstowe hybrydy. Literackość i jej pogranicza. 161-203. Wrocław: Funna. 
Hutcheon Linda. 2007. Teoria parodii. Lekcja sztuki XX wieku, przeł. Agnieszka Wojtanowska, Witold Wojtowicz. Wrocław: Wydawnictwo Atut.

Jakowska Krystyna. 1983. Powrót autora: renesans narracji auktorialnej w polskiej powieści międzywojennej. Wrocław: Zakład Narodowy im. Ossolińskich. Wydawnictwo Polskiej Akademii Nauk.

Kayser Wolfgang. 2003. „Próba określenia istoty groteskowości”, przeł. Ryszard Handke. W: Groteska, red. Michał Głowiński. 17-30. Gdańsk: słowo/obraz terytoria.

Kierkegaard Søren. 1999. O pojęciu ironii z nieustającym odniesieniem do Sokratesa, przeł. Alina Djakowska. Warszawa: K.R.

Łaguna Piotr. 1984. Ironia jako postawa i jako wyraz. Wrocław: Wydawnictwo Literackie.

Nowotny-Szybistowa Magdalena. 1973. Osobliwości leksykalne w języku Stanisława Ignacego Witkiewicza. Wrocław: Zakład Narodowy im. Ossolińskich. Wydawnictwo Polskiej Akademii Nauk.

Nycz Ryszard. 2000. Tekstowy świat. Poststrukturalizm a wiedza o literaturze. Kraków: Universitas.

Onimus Jean. „Groteskowość a doświadczenie świadomości”, przeł. Krystyna Falicka. W: Groteska, red. Michał Głowiński. 73-86. Gdańsk: słowo/ /obraz terytoria.

Ososiński Tomasz. 2014. Ironia a jednostka. Koncepcja ironii Friedricha Schlegla i Sokratesa. Warszawa: Wydawnictwo Uniwersytetu Warszawskiego.

Patyk Romana. 2004. „Sokrates wiszący”. Edukacja Filozoficzna 37: 269-281.

Reale Giovanni. 1999. Historia filozofii starożytnej, przeł. Edward Iwo Zieliński. T. 2. Lublin: Wydawnictwo KUL.

Schlegel Friedrich. 2009. Fragmenty, tłum. Carmen Bartl, oprac. Michał Paweł Markowski. Kraków: Wydawnictwo UJ.

Skwara Marta. 2012. Wśród Witkacoidów: w świecie tekstów, w świecie mitów. Wrocław: Wydawnictwo Uniwersytetu Wrocławskiego.

Słowiński Mirosław. 1990. Błazen. Dzieje postaci i motywu. Poznań: Wydawnictwo Poznańskie.

Sokół Lech. 1973. Groteska w teatrze Stanisława Ignacego Witkiewicza. Wrocław: Zakład Narodowy im. Ossolińskich. Wydawnictwo PAN.

Speina Jerzy. 1965. Powieści Stanisława Ignacego Witkiewicza. Forma i struktura. Torun: Towarzystwo Naukowe.

Sznajderman Monika. 2014. Błazen. Maski i metafory. Warszawa: Iskry.

Witkiewicz Stanisław Ignacy, Ingarden Roman. 2002. Korespondencja filozoficzna, oprac. Bohdan Michalski. Warszawa: Wydawnictwo IFiS PAN.

Witkiewicz Stanisław Ignacy. 1993. Jedyne wyjście, oprac. Anna Micińska. Warszawa: Państwowy Instytut Wydawniczy.

Witkiewicz Stanisław Ignacy. 1993. Narkotyki. Niemyte dusze, oprac. Anna Micińska. Warszawa: Państwowy Instytut Wydawniczy.

Witkiewicz Stanisław Ignacy. 2002. „Nowe formy w malarstwie i wynikające stąd nieporozumienia". W: Stanisław Ignacy Witkiewicz, Nowe formy w malarstwie i wynikajace stad nieporozumienia. Szkice estetyczne, oprac. Janusz Degler, Lech Sokół. Warszawa: Państwowy Instytut Wydawniczy. 
Witkiewicz Stanisław Ignacy. 2002. "Pojęcia i twierdzenia implikowane przez pojeccie Istnienia". W: Stanisław Ignacy Witkiewicz, "Pojęcia $i$ twierdzenia implikowane przez pojęcie Istnienia" i inne pisma filozoficzne (1902-1932), oprac. Bohdan Michalski. 145-354. Warszawa: Państwowy Instytut Wydawniczy.

Witkiewicz Stanisław Ignacy. 2003. O Czystej Formie i inne pisma o sztuce, oprac. Janusz Degler. Warszawa: Państwowy Instytut Wydawniczy.

Witkiewicz Stanisław Ignacy. 2014. „O idealizmie i realizmie”. W: Stanisław Ignacy Witkiewicz, »Nauki ścisłe a filozofia $i$ inne pisma filozoficzne (1933-1939), oprac. Maciej Dombrowski i Magdalena Bizior-Dombrowska. 94-160. Warszawa: Państwowy Instytut Wydawniczy.

Wittgenstein Ludwig. 2000. Tractatus logico-philosophicus, przeł. Bogusław Wolniewicz. Warszawa: Wydawnictwo Naukowe PWN.

Zofia Mitosek. 2003. „Jak ugryźć Witkacego (Stanisław Ignacy Witkiewicz »Jedyne wyjście«)". W: Zofia Mitosek, Poznanie (w) powieści - od Balzaka do Masłowskiej. 156-172. Kraków: Universitas.

Żmigrodzka Maria. 1986. „Etos ironii romantycznej po polsku”. W: Problemy wiedzy o kulturze, red. Alina Brodzka, Maryla Hopfinger, Janusz Lalewicz. 521-534. Wrocław: Zakład Narodowy im. Ossolińskich.

Żmigrodzka Maria. 1994. „Ironia romantyczna”. W: Słownik literatury polskiej XIX wieku, red. Józef Bachórz, Alina Kowalczykowa. 378-379. Wrocław: Ossolineum.

\section{Streszczenie}

W artykule staram się pokazać, w jaki sposób można interpretować dzieła Witkacego poprzez rzadko przywoływaną w tym kontekście kategorię ironii. Zajmuję się problemem stwarzającego liczne problemy interpretacyjne stylu Witkiewicza. Staram się pokazać, że przekazu, który płynie z dzieł Witkiewicza, nie należy interpretować jako wyraźnie groteskowego i parodystycznego, a ironię i parodię lub groteskę można pogodzić z uznaniem tematów "poważnych" $\mathrm{i}$ „pedagogicznych" w jego pracach. Jako przykład tej procedury proponuję analizę ostatniej powieści Witkiewicza - Jedyne wyjście, gdzie stara się on zaproponować własną doktrynę filozoficzna, a ta strategia ukryta jest pod płaszczykiem powieści.

Słowa kluczowe: Witkacy, powieść, ironia, parodia, groteska, filozofia 


\section{Summary}

\section{Witkacy's Irony in the Philosophical Context. Around the Jedyne wyjście by S. I. Witkiewicz}

In this article, I try to show how the category of irony rarely invoked in the philosophical context can be used in the interpretation of Witkacy's works. I deal with the problem of Witkiewicz's style, which poses numerous interpretational problems. I try to show that the message of the works by Witkiewicz should not be read as clearly grotesque and parodic and that both the irony and parody or grotesque can be reconciled with the recognition of "serious" and "pedagogical" topics in his works. As an example of this procedure I propose the analysis of the latest Witkiewicz's novel, Jedyne wyjście (The Only Way Out), where he tries to propose his own philosophical doctrine and this strategy is hidden under the cover of the novel.

Keywords: Witkacy, novel, irony, parody, grotesque, philosophy 